\title{
Where do the salts go? \\ The potential effects and management of salt accumulation in south-central Arizona
}

\section{Introduction}

Land in arid and semiarid regions of the world is irrigated to sustain agriculture, urban yards and lawns, and other vegetation. To prevent the accumulation of salts in the root zone, the quantity of water applied must be sufficient to flush the salts beyond the root zone as well as meet the plant requirements. Many factors determine the extent and severity of salt accumulation including chemical composition of the water supply; nature and composition of the soil and subsoil; topography of the land; quantity of water used and the methods of applying it; kinds of crops grown; climate of the region, especially the quantity and distribution of rainfall; and nature of groundwater and surface-water drainage systems (Hem, 1985). Irrigated agriculture can result in rising water tables, waterlogged soils, progressive mineralization of water and soils, briny wastewater-disposal problems and concerns, and contamination of ground water by fertilizers and pesticides applied to the land and by chemicals in treated sewage effluent when it is used for irrigation (Bouwer, 1990; Bouwer and others, 1998).

In south-central Arizona, the conversion of desert and rangeland to irrigated agricultural and urban land has been possible because of the impoundment of rivers, the pumping of ground water, and the importation of water. The salts that remain in the soil when these waters are used for irrigation are of concern because they can adversely affect crop production; quality of the underlying ground water; and domestic, municipal, and industrial water uses. In order to understand the causes and effects of salt accumulation in water and soils and how to manage or mitigate those effects, we need to understand where the salts come from and where they go.

\section{What are salts?}

The terms "salt content" or "salinity" of water actually refer to the quantity of mineral constituents that are dissolved in the water. The dissolved minerals or salts in water typically are reported as the

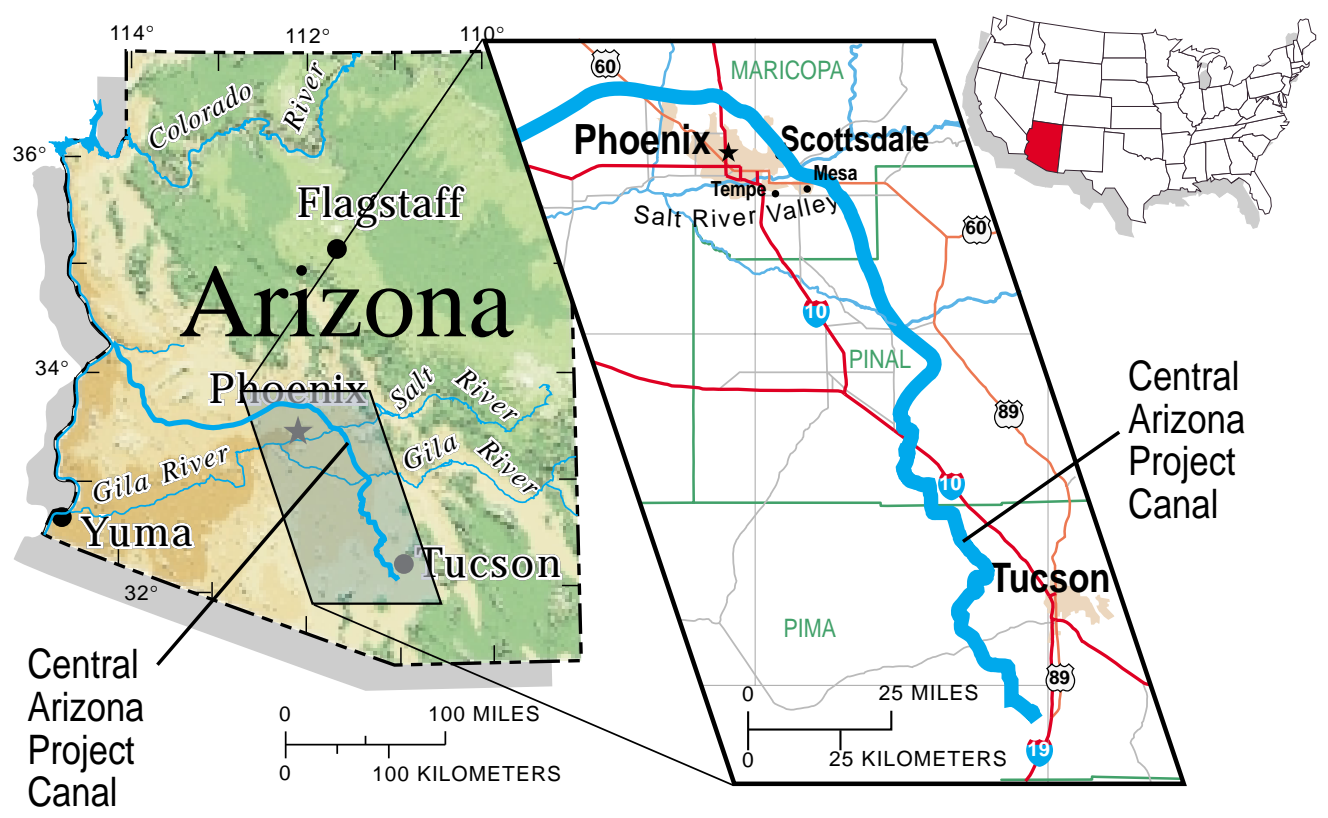

A lesson from an ancient civilization

The accumulation of salts in soils and ground water in arid and semiarid regions as a result of agricultural and irrigation practices is as much a concern to modern civilizations as it was to ancient civilizations. For example, the flood plain of the Tigris and Euphrates Rivers, known as the "Fertile Crescent" in ancient Mesopotamia (presentday Iraq), was first irrigated more than 6,000 years ago. The resulting agricultural surplus provided the foundation upon which the civilization was built; however, canals built in 4000 B.C. did not sufficiently drain excess water from the agricultural areas, and salts accumulated in water and soils. Progressive waterlogging and salinization were evident from the historical succession of crops - a 50/50 split of wheat and barley was grown in about 3500 B.C.; by 2500 B.C., the more salt-tolerant barley represented 80 percent of the crop, and finally by 1700 B.C., wheat could not be grown because of the salts that had accumulated in the ground water and soil. Centuries of irrigating poorly drained soil with highly mineralized water in an arid climate left a thick crust of salt on the land surface and soil hardened by salt deposits. By 1950, 60 percent of the tillable land in the area was affected by salt accumulation (Earthscan, 1984). A more recent example is the western desert of Egypt on the fringe of the Nile River delta. Irrigation began in 1956, and in 5 years, salinization of ground water and waterlogging of crop lands were causing deterioration in crop production (Hassan and others, 1979). As Scofield (1938) noted, "The application of irrigation water in abundance to soils in arid regions may have consequences unsuspected by those engaged in developing projects and farmers settling on the land."

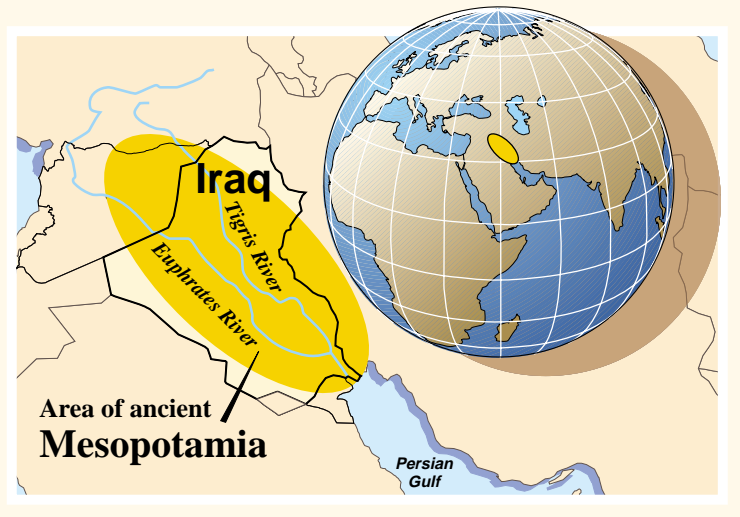


"dissolved-solids concentration" in milligrams of dissolved salts in one liter of water $(\mathrm{mg} / \mathrm{L})$. Water with a dissolved-solids concentration of less than $500 \mathrm{mg} / \mathrm{L}$-about a quarter of a teaspoon of salts per gallon of water-generally is suitable for most uses (Swenson and Baldwin, 1965). Water may have a mineralized or salty taste when the dissolved-solids concentration exceeds $500 \mathrm{mg} / \mathrm{L}$, which is the Federal secondary maximum contaminant level for drinking water (U.S. Environmental Protection Agency, 1994). At concentrations greater than $2,000 \mathrm{mg} / \mathrm{L}$, water generally is unsuitable for many uses including longterm irrigation (Swenson and Baldwin, 1965). The salts that constitute a major part of the dissolved-solids concentration in waters of south-central Arizona are calcium, magnesium, sodium, sulfate, chloride, and bicarbonate. Concentrations of nitrate, fluoride, and trace metals such as arsenic or selenium are particularly significant because they affect the suitability of water for certain purposes (Hem, 1985).

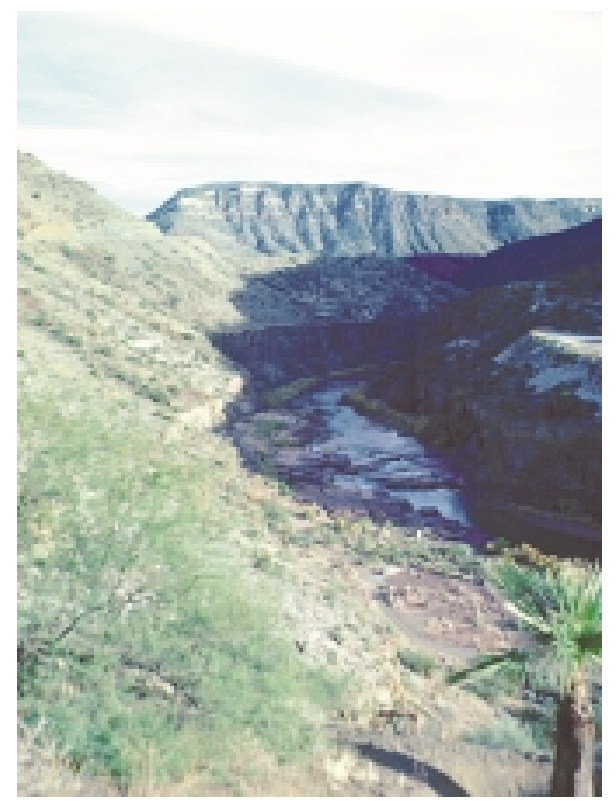

Salt River, east of Phoenix, Arizona. (Photograph by Gail Cordy.)

\section{Where do the salts come from?}

Natural processes add salts to surface water and ground water. The concentration of salts in water is determined by many factors including reactions with minerals in the soil and rock formations across which and through which the water moves. For example, the average dissolved-solids concentration of the Salt River as it enters the Salt River Valley east of Phoenix (Salt River below Stewart Mountain Dam) is

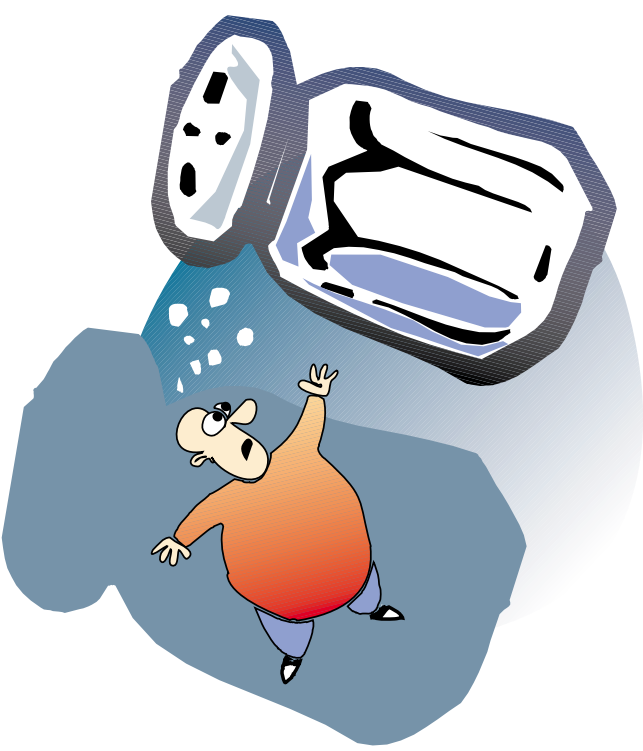

\section{The total imported salt load in south-central Arizona equals about 900 pounds of salts per person per year!}

about 480 mg/L (Baldys and others, 1995). The average concentration of imported lower Colorado River water used in the area (Central Arizona Project Canal at 7th Street in Phoenix) is about $580 \mathrm{mg} / \mathrm{L}$ (David Anning, hydrologist, U.S. Geological Survey, oral commun., 1998). Ground water in south-central Arizona generally has a dissolved-solids concentration of less than $500 \mathrm{mg} / \mathrm{L}$; however, higher concentrations are present in many areas.

Human activities also can add salts to natural waters. For example, irrigation water may leach mineral constituents from the soil and deeper geologic formations and carry them to the ground water, which in turn, can discharge to surface water where the water table intersects the land surface. Mining activities can release dissolved mineral constituents to local streams and ground water. Storm runoff from urban areas and municipal wastewater also can contribute salts and chemicals.

The Salt and Colorado Rivers bring not only water into central Arizona, but also salts_about 1.1 million tons for the estimated 1.4 million acre-feet (Central Arizona Project, 1998) of Colorado River water imported in 1997 through the Central Arizona Project (CAP) canal, and about 520,000 tons in the roughly 0.8 million acre-feet (Tadayon and others, 1998) of Salt River water that flowed into the greater Phoenix area in 1997. This is a total imported salt load of about 1.6 million tons per year, the equivalent to a half-ton pickuptruck load of salts entering the area about every 10 seconds or about 900 pounds of salts per person per year for each of the 3.6 million people in south-central Arizona in 1997 (estimate for Maricopa, Pinal, and Pima Counties from Valerie Rice, University of Arizona, Economic and Business Research Program, oral commun., 1998). An equal quantity of salts would have to leave the area to maintain a salt balance. Yet there is no substantial removal of salts from the area because almost all of the water from the Salt River and the CAP canal is used in south-central Arizona (David Anning, oral commun., 1998). So where do the salts go?

\section{Where do the salts go?}

The answer is simple-The salts go where the water goes, and they accumulate in soils where evapotranspiration (combined evaporation from soils and transpiration by plants) exceeds combined precipitation and irrigation. For south-central Arizona, salts accumulate in irrigated agricultural and urban areas (parks, golf courses, and residential yards). The water that is returned to the atmosphere by evapotranspiration essentially is distilled water, leaving the

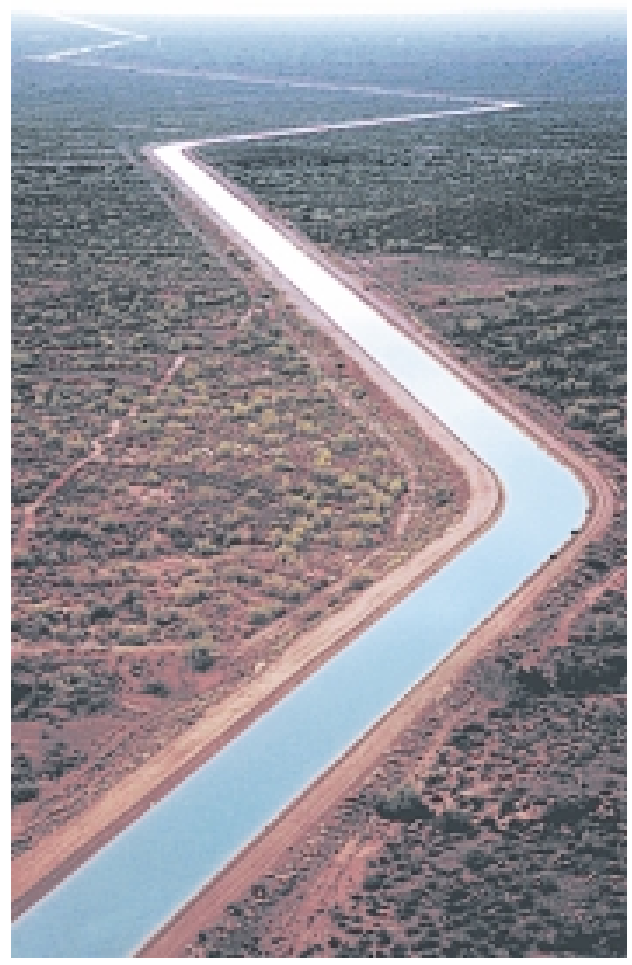

Central Arizona Project Canal, west of Phoenix, Arizona. (Photograph by Darryl Webb, Mesa Tribune, published with permission.) 


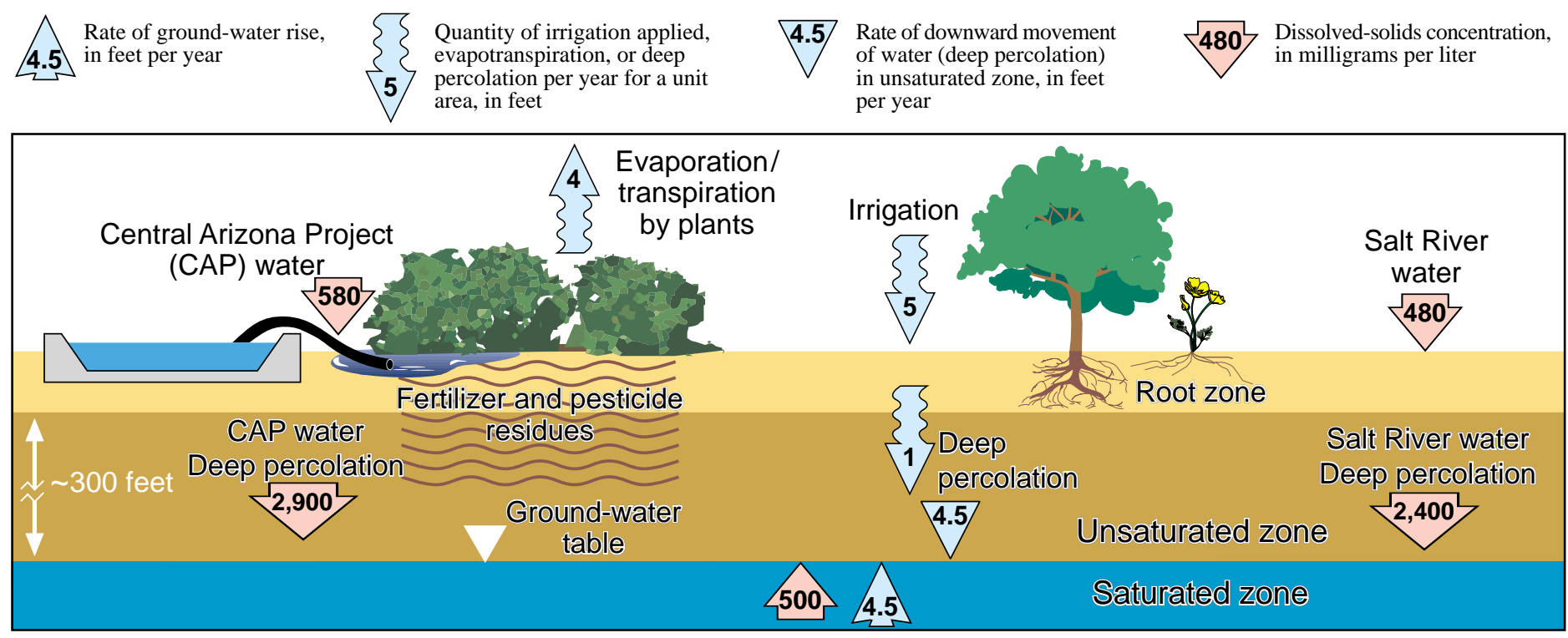

Diagrammatic illustration showing quantity of irrigation, evapotranspiration, or deep percolation; rate of ground-water movement; and dissolved-solids concentration for waters in the Salt River Valley, Phoenix, Arizona.

salts in surficial soils and in the root zones of plants. To avoid salinity damage and possibly killing plants or crops, the salts brought in by irrigation water must be leached from the root zone by applying more irrigation water than can be evaporated. The leaching results in sustainable crop production and plant growth.

Generally, the leach water or deeppercolation water continues to move downward through the soil and basin-fill sediments of the unsaturated zone until it reaches the ground water (saturated zone).

As an example (see illustration above), consider cotton grown in south-central Arizona with an efficient irrigation system that applies 5 feet of water per year, of which 4 feet are evaporated or transpired (Erie and others, 1982), and about 1 foot leaches salts from the root zone. The leaching process produces 1 foot per year of deep-percolation water that moves down to the ground-water table; however, this 1 foot of water per year contains almost all of the dissolved salts from 5 feet of irrigation water. As a result, salt concentrations in the deep-percolation water will be as much as 5 times higher (Bouwer, 1990) than those of the original irrigation water - about $2,400 \mathrm{mg} / \mathrm{L}$ if water from the Salt River is used and 2,900 $\mathrm{mg} / \mathrm{L}$ if water from the CAP canal is used.

\section{What are the potential effects of salt ac cumulation in ground $w$ ater?}

During much of this century, more ground water has been withdrawn in south-central Arizona than has been replenished by natural and artificial means (Arizona Department of Water Resources, 1994). As a result, ground-water levels generally have moved downward more quickly than the deep-percolation water from agricultural fields and urban areas, and the quality of deep ground water has not been degraded by the slower moving salty water (Bouwer, 1997). Since the mid-1980's, the trend has been to rely less on ground water and use more CAP water, especially for agriculture (Cordy and others, 1998). This trend could result in ground-water levels declining more slowly or even beginning to rise. Water levels also would rise if salty deeppercolation water reaches the ground-water table.

In the southeastern part of the Salt River Valley where irrigation has continued but ground-water pumping has stopped, groundwater levels have risen an average of about 4.5 feet per year in the last 15 years, and the concentration of salts in shallow ground water has increased (Karol Wolf, hydrogeologist, Salt River Project, oral commun., 1998). By applying this rate of water-level rise to other areas in south-central Arizona, ground water at a depth of 300 feet today could rise to the land surface in about 70 years if pumping was discontinued and all of the deep-percolation water continued to reach the water table. Rates of rise in ground-water levels depend on the water storage capacity (interconnected pore space between soil grains) and water content of the soils above the water table, the quantity of irrigation water applied, the quantity of evapotranspiration, and the natural recharge from precipitation and surface runoff. As previously noted, the deep-percolation water could contain about $2,400 \mathrm{mg} / \mathrm{L}$ of salts if water from the Salt River is used for irrigation and $2,900 \mathrm{mg} / \mathrm{L}$ if water from the CAP canal is used. In addition to the salts, ground water may contain elevated concentrations of contaminants from fertilizer and pesticide applications, especially where ground-water levels are near the land surface.

\section{As salty ground water approaches land surface, plants begin to show signs of salinity damage and die from salty water in the root zone and waterlogging, basements may flood, water levels may rise into landfills, and underground pipes can be damaged.}

If water levels are allowed to remain at or near land surface, salt marshes and salt flats could form. How can the salty ground water be managed to prevent these problems?

\section{How can the salty ground water be managed?}

Because salinization of ground water and soils is a common problem in arid and semiarid parts of the world where land is irrigated, many solutions have been proposed and tested. The salt load can be reduced through improved irrigation practices or modifications in cropping practices that reduce deep-percolation losses (Ayars and other, 1997). Improved irrigation practices might include reducing preplanting irrigation, using different irrigation technologies such as drip systems that deliver water directly to each plant, and 
using shallow ground-water management techniques such as tile drains to collect the salty water where ground-water levels are high. Cropping modifications could include allowing some land to lie fallow, growing crops using dryland techniques, and retiring land from agricultural use.

If ground water in the upper parts of the aquifers is contaminated by deep-

percolation water, it could be too salty for drinking or irrigation of salt-sensitive crops; however, there are several options for managing the salty water. One option is to pump ground water from the upper parts of the aquifers to stabilize ground-water levels at acceptable depths (Bouwer, 1997). This salty water could then be disposed of in evaporation lakes after minimizing the volume of water and maximizing the salt content by sequential irrigation of increasingly salt-tolerant plants (Shannon and others, 1997). In this process, the deeppercolation water from salt-sensitive crops like vegetables is captured and used to irrigate a more salt-tolerant crop, such as cotton, from which the deep-percolation water could be used on very salt-tolerant plants ending with halophytes (extremely salt-tolerant plants). The salty water at the end of the process could be managed in evaporation lakes; however, these lakes can become environmental hazards by creating areas of high salt concentrations that can be detrimental to animals and plants.

Another option is to desalt the pumped ground water using reverse osmosis or other membrane-filtration processes. Desalting produces a reject brine that can be stored indefinitely in lined evaporation ponds. Salty deep-percolation water and (or) reject brines could be injected into deep wells far below the potable ground water; however, Federal regulations must be met in the selection of disposal wells, and the migration of these waters into potable water supplies cannot always be predicted or controlled. A third option is to convey the leach water and (or) brines by a "brine line" to the lower end of the Colorado River for commercial desalinization (reverse osmosis) and (or) for expanding wetlands at the end of the Colorado River (Bouwer, 1997). Other options are possible, but the accumulation of salts in ground water and waterlogging of soils in south-central Arizona could cause significant problems if practices that allow salt accumulation continue.

—Gail Cordy (USGS) and Herman Bouwer (USDA)

\section{References Cited}

Arizona Department of Water Resources, 1994, Arizona water resources assessment, v. I, Inventory and Analysis: Phoenix, Arizona Department of Water Resources report, August 1994, p. 51.

Ayars, J.E., Soppe, R.W., Cone, D., and Wichelns, D., 1997, Managing salt load in irrigation district drainage water, in Findikakis, A.N., and Stauffer, Fritz, eds., Groundwater: An endangered resource: International Association for Hydraulic Research, 27th Congress, San Francisco, California, August 10-15, 1997, Proceedings, p. 277-282.

Baldys, Stanley, III, Ham, L.K., and Fossum, K.D., 1995, Summary statistics and trend analysis of water-quality data at sites in the Gila River Basin, New Mexico and Arizona: U.S. Geological Survey Water-Resources Investigations Report 95-4083, 86 p.

Bouwer, Herman, 1990, Agricultural chemicals and groundwater quality: Journal of Soil and Water Conservation, v. 45, no. 2, p. 184-189.

1997, Arizona's long-term water outlook: From NIMTO to AMTO: Arizona Hydrological Society Newsletter, v. 14, April and May issues.

Bouwer, Herman, Fox, Peter, and Westerhoff, Paul, 1998, Irrigating with treated effluent: How does this practice affect underlying ground water?: Water Environment and Technology, v. 10, no. 9, p. 115-118.

Central Arizona Project, 1998, Achieving the dream: Central Arizona Project 1977 Annual Report, Phoenix, Arizona, $44 \mathrm{p}$.

Cordy, G.E., Rees, J.A., Edmonds, R.J., Gebler, J.B., Wirt, L., Gellenbeck, D.J., and Anning, D.W., 1998, Water-quality assessment of the Central Arizona Basins, Arizona and northern Mexico-Environmental setting and overview of water quality: U.S. Geological Survey Water-Resources Investigations Report 98-4097, 72 p.

Earthscan, 1984, Cropland or wasteland: The problem and promises of irrigation: Earthscan Press Briefing Document No. 38, 97 p.

Erie, L.J., French, O.F., Bucks, D.A., and Harris, K., 1982, Consumptive use of water by major crops in the southwestern United States: U.S. Department of Agriculture, Agricultural Research Service, Conservation Research Report Number 29, 40 p.

Hassan, M.N., Marei, S., Motagalli, M., El Abd, H., and Arnaout, S., 1979, Salinity hazard and water logging in the area west of Noubaria canal, in Bishay, Adli, and McGinnies, W.G., eds., Advances in desert and arid land technology and development: International Conference on Applications of Science and Technology for Desert Development, Cairo, Egypt, September 9-15, 1978, Proceedings, p. 85-95.

Hem, J.D., 1985, Study and interpretation of the chemical characteristics of natural water: U.S. Geological Survey Water-Supply Paper 2254, p. 213-217.
Shannon, M., Cervinka, V., and Daniel, D.A., 1997, Drainage water reuse, in Madramootoo, C.A., Johnston, W.R., and Willardson, L.S., eds., Management of Agricultural Drainage Water Quality: Food and Agricultural Organization of the United Nations, Water Report No. 13, Rome, p. 29-40.

Scofield, C.S., 1938, Soil, water supply, and soil solution in irrigation agriculture, in Soils \& Men, Yearbook of Agriculture 1938: U.S. Department of Agriculture, p. 705-716.

Swenson, H.A., and Baldwin, H.L., 1965, A primer on water quality: U.S. Geological Survey, Washington, D.C., 27 p.

Tadayon, Saeid, Duet, N.R., Fisk, G.G., McCormack, H.F., Pope, G.L., and Rigas, P.D., 1998, Water resources data, Arizona, water year 1997: U.S. Geological Survey Water-Data Report AZ-97-1, p. 220.

U.S. Environmental Protection Agency, 1994, National revised secondary drinking water regulations-Secondary maximum contaminant levels: Washington, D.C., U.S. Environmental Protection Agency, U.S. Code of Federal Regulations, Title 40, section 143.3, July 1, 1994, p. 836.

\section{For further information contact:}

Gail Cordy

U.S. Geological Survey

520 N. Park Avenue, Suite 221

Tucson, Arizona 85719-5035

(520) 670-6671

E-mail:gcordy@usgs.gov

or visit our home page

http://az.water.usgs.gov/cazb

Dr. Herman Bouwer

U.S. Water Conservation Laboratory

4331 E. Broadway Road

Phoenix, Arizona 85040-8832

(602) 379-4356

E-mail:hbouwer@uswl.ars.ag.gov

or visit our home page

http://www.uswcl.ars.ag.gov

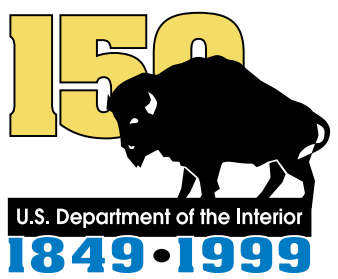

